\title{
Mountain protected areas as refuges for threatened freshwater species: the detri- mental effect of the direct introduction of alien species
}

\author{
Marco Bonelli, Raoul Manenti \& Davide Scaccini
}

Keywords: white-clawed crayfish; local extinction; spiny-cheek crayfish; crayfish plague; alien species introduction; natural barrier

Abstract

One of the main threats to native European crayfish species is presented by the spread of invasive ones, which are vectors of the crayfish plague Aphanomyces astaci. In particular, the Austropotamobius pallipes complex is suffering extensive decline in its whole distribution range. In this paper, we describe a case of extinction of a native population of the A. pallipes complex driven by the direct human introduction of the alien species Orconectes limosus, in a mountain protected area in northern Italy. The local extinction event of the native crayfish population is reported, and the factors that drove it are reconstructed. Our results help to better understand the threats to native crayfish species occurring even in protected areas, as well as to establish proper prevention and management actions.

\section{Profile}

Protected area

Monte Barro Regional

Park

Mountain range

Alps, Italy

\section{Introduction}

Mountain protected areas (PAs) are usually considered crucial for the conservation of several biodiversity elements. Although only a limited number of these areas are designed or managed with the specific goal of conserving freshwater biodiversity (Chessman 2013), protected mountain areas generally may be important refuges for highly endangered aquatic species (Schauer et al. 2012). Native crayfish species (Decapoda: Astacidae) are currently among the most threatened organisms of the European freshwater fauna. While in the past they were widespread in all the river networks from springs to estuaries, currently they are often confined to mountain and hilly areas in the upper reaches of first-order creeks and streams (Westman et al. 2002; Nardi et al. 2005; Manenti et al. 2014).

Native crayfishes are threatened by habitat loss, fragmentation and alteration, pollution, overharvesting, climate change, and the introduction of alien species and epizootic diseases (Sala et al. 2000; Edgerton et al. 2004; DAISIE 2009; Holdich et al. 2009; Hulme 2009; Capinha et al. 2013; Chucholl 2013; Markovic et al. 2014).

The native white-clawed crayfish Austropotamobius pallipes complex has been included in the IUCN (International Union for Conservation of Nature) Red Data List as Endangered (EN) (Füreder et al. 2010). Populations of the white-clawed crayfish have declined enormously in the past few years and the species' range has been drastically reduced, such that conservation strategies have become mandatory (Kozák et al. 2011). In several territories in Italy, the white-clawed crayfish is considered to be on the verge of extinction (Fea et al. 2006; Brusconi et al. 2008). An understanding of the factors that cause a native species to become extinct is important for the devel- opment of an effective and appropriate conservation strategy for the future.

A key issue for the conservation of native crayfish species is to avoid the spread of alien ones. Most of the non-native crayfish species currently established in European waters have apparently been introduced by anthropogenic activities, e. g. for aquaculture purposes or, to lesser extent, via the aquarium trade (Gozlan et al. 2006; Holdich et al. 2009). The spread of alien species by human activity often has a serious impact on native species (Strayer 2010), and PAs are expected to play a key role in the preservation of the native ecosystem.

In particular, three American freshwater crayfishes are significantly harmful to native European ones: Pacifastacus leniusculus (Dana, 1852) (Decapoda: Astacidae), Procambarus clarkii (Girard, 1852) and Orconectes (Faxonius) limosus (Rafinesque, 1817) (Decapoda: Cambaridae). Moreover, they also have a strong negative impact on freshwater communities generally, affecting both aquatic and semi-aquatic organisms (Gherardi 2007; Strayer 2010; Ficetola et al. 2011; Manenti et al. 2014).

These three American freshwater crayfish species are vectors of the crayfish plague pathogen Aphanomyces astaci Schikora, 1906 (Oomycetes: Saprolegniales) (Oidtmann 2012), which is listed in the top 100 of the world's most invasive species by the IUCN (Lowe et al. 2000; Gerlach et al. 2014). A. astaci was first recorded in Europe in the 1860s, in the Po Valley (northern Italy) (Cornalia 1860; Martinati 1861; Ninni 1865). Since the second half of the nineteenth century, the pathogen has affected the populations of native European crayfish extensively, causing several extinction events (Alderman 1996; Holdich et al. 2009).

All the North American crayfish species investigated are potential carriers of the plague (Söderhäll \& 


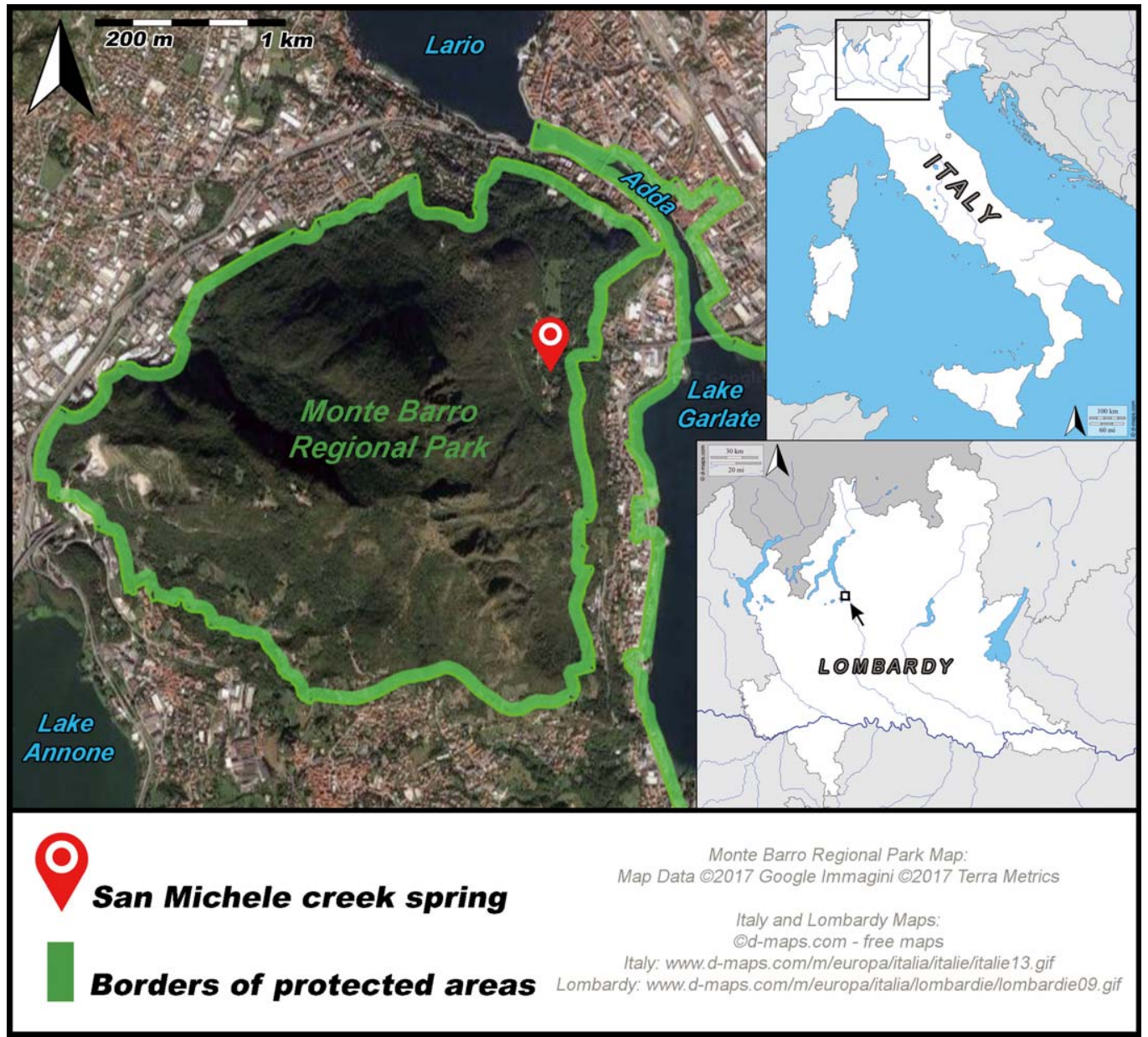

Figure 1 - Location of the study site; the marker indicates the location of the San Michele creek spring in the Monte Barro Regional Park.

Cerenius 1999; Oidtmann 2012). The Old NICS (Old Non Indigenous Crayfish Species; Holdich et al. 2009) in particular, P. leniusculus, $P$. clarkii and O. limosus, are often $A$. astaci-hosts.

The aim of this paper is to describe a case of extinction of a native population of the $A$. pallipes complex in a mountain PA in Lombardy (NW Italy) and to identify the factors that caused this event. Our results demonstrate that, after the introduction of the spiny-cheek crayfish $O$. limosus in the creek, A. astaci plague brought about the extinction of the native species. In addition, we tried to uncover how the alien species had been introduced into the area. Our results evidence the importance of including programmes of supervision for small freshwater habitats in the management plans of mountain PAs.

\section{Material and methods}

Our research is focused on the San Michele creek situated in the Monte Barro Regional Park (Figure 1), in the Lecco province (NW Italy). The park is an Alpine PA (ALPARC 2016) and a Site of Community Importance (SCI), as defined by the European Commission Habitats Directive (92/43/EEC). The Monte
Barro is a mountain of the Lugano preAlps (Marazzi 2002).

The San Michele creek rises from a spring located in the area of the same name (situated in Galbiate $\mathrm{Mu}$ nicipality, Figure 2), on the eastern side of the Monte Barro (WGS84/UTM32N, E530192, N5076023, $340 \mathrm{~m}$ a.s.l.). The flow rate of the spring is estimated to be 81 per minute. Riparian vegetation consists of both deciduous trees and understorey plants, with a large number of ferns. A few metres downstream from the spring, a pool with permanent water occurs (Figure 3). The creek is perennial only in its initial stretch, then runs into a 60-metre high waterfall and meets permeable substrates, where the water is present only during periods of high rainfall. Finally, the creek flows into Lake Garlate and the river Adda. Both the presence of the waterfall and, downstream from it, the temporary nature of the presence of water acted as barriers for the spread of the invasive crayfish O. limosus, which was already established in the Lario (also known as Lake Como), which is nearby, in 2006 if not earlier (Manenti 2006). The San Michele creek hosted a well-structured population of the $A$. pallipes complex, which has been surveyed periodically since 2003 (Manenti 2006, and unpublished data). 
From March to June 2013, we carried out nighttime visual encounter surveys of native crayfishes occurring in the creek, estimating the Catch per Unit Effort (CPUE) index (Zimmerman \& Palo 2011). From 26 July 2013, when O. limosus were first recorded in the creek, we started to remove individuals of the allochthonous species, taking at least three samplings per night.

Samplings were carried out on 26 and 30 July 2013, and monthly from August to October 2013. Periodical surveys of the creek were performed also from March to October 2014, and from March to October 2015. The samplings were taken between 21:00 to 01:00, by the same observers.

\section{Results}

From March to June 2013, the population density of the $A$. pallipes complex was fairly constant, with relatively high CPUE values (mean value \pm SEM: 3.5 $\pm 0.26)$. In May, we also observed throughout the entire stretch of the creek the presence of numerous new-born native crayfishes. However, on 26 July 2013 we recorded several dead native crayfishes (Figure 4), and one dying individual (Figure 5). This moribund specimen showed features typical of $A$. astaci infection (Oidtmann 2012), especially behavioural and physiological changes such as uncoordinated movements, reducing the tail escape reflex, and progressive paralysis and instability. Moreover, on the same occasion many O. limosus individuals were recorded in the creek. No further individual of the $A$. pallipes complex was recorded after July 2013.

Immediately following the first recording of the spiny-cheek crayfish, we started to perform a first sampling for the removal of O. limosus individuals, collecting 32 specimens $(25$ males and 7 females; sex ratio 3.57:1) (Figure 6). Their lengths varied from 70 to $110 \mathrm{~mm}$. Attached between its gonopods, one of the males showed a zebra mussel Dreissena polymorpha (Pallas, 1771) (Veneroida: Dreissenidae) (Figure 7), a mollusc inhabiting standing waters or slow running rivers, which is common in the Lario. In the following three surveys (30 July, 15 August and 22 September 2013), 15 other $O$. limosus specimens ( 10 males and 5 females; sex ratio 2.00:1) in the same size range were collected. In total 47 specimens ( 35 males and 12 females; sex ratio 2.92:1) were removed from the stream. After these surveys, from October 2013, we did not observe any further $O$. limosus individual in the creek.

\section{Discussion}

We report the sudden extinction of a population of the $A$. pallipes complex in a mountain PA. We hypothesize that the extinction of this species complex was immediately successive to the illegal introduction of the spiny-cheek crayfish $O$. limosus, and that the pathogen $A$. astaci was responsible for the mass

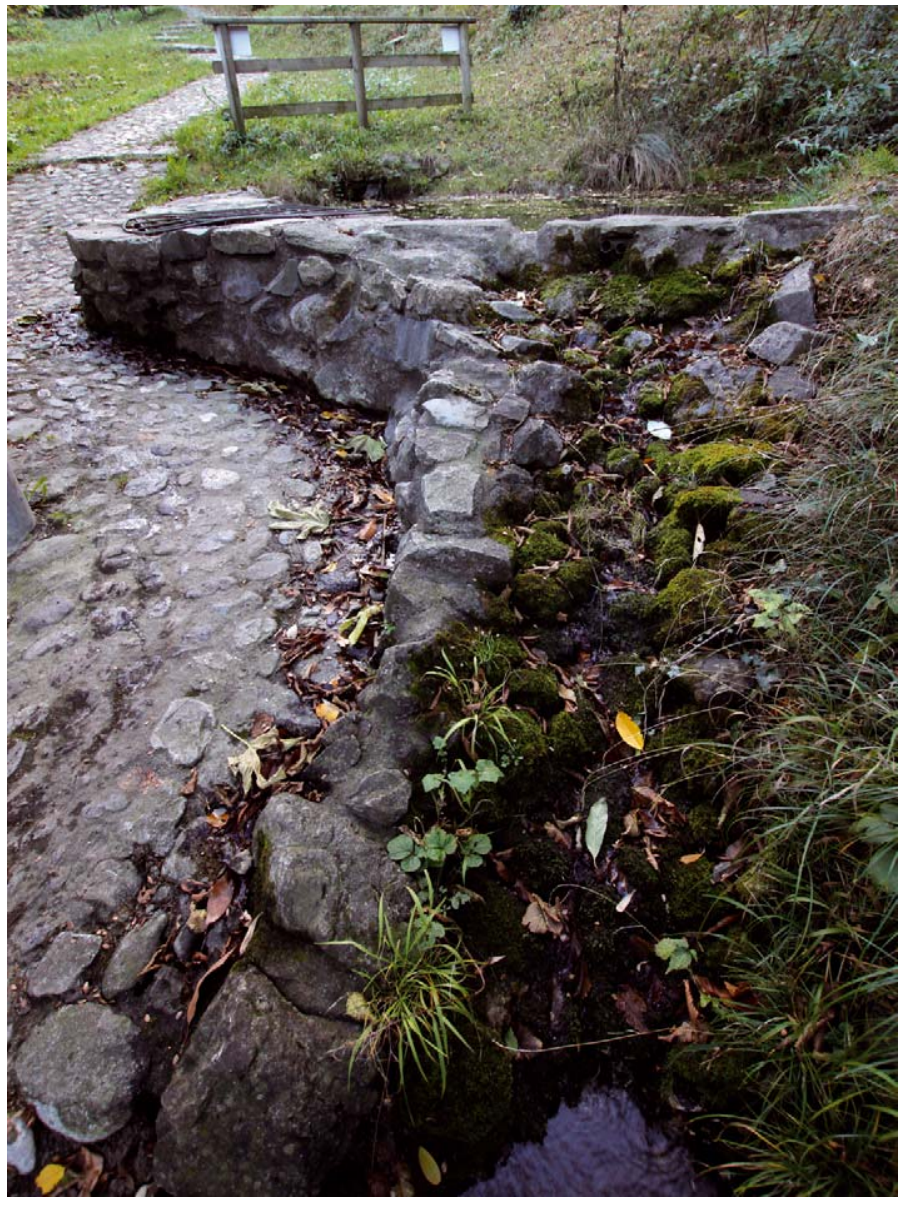

Figure 2 - The San Michele creek spring. (C) M. Bonelli 2016

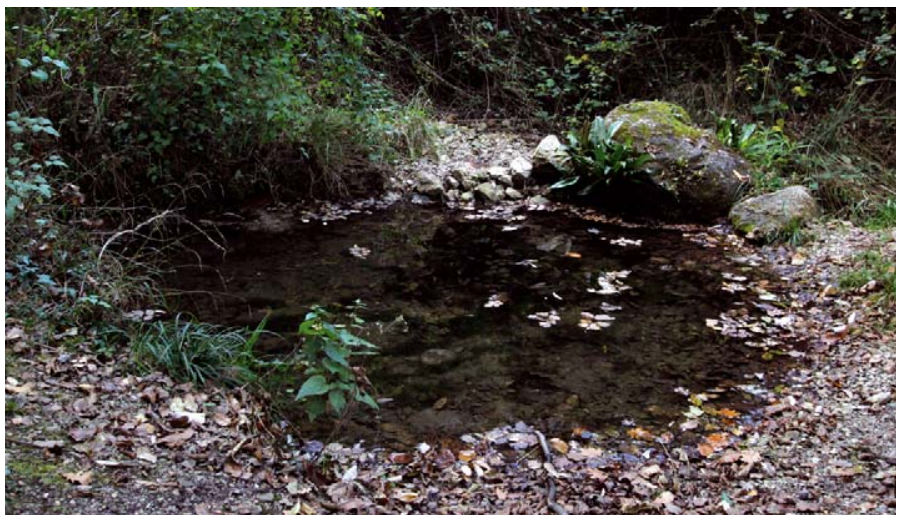

Figure 3 - The pool with permanent water, San Michele creek. (C) M. Bonelli 2016

mortality of all the native crayfishes present in the isolated creek. The similarity in size of the recorded O. limosus individuals, the occurrence of a typical lake species such as $D$. polymorpha attached between the gonopods of a male, and the sudden appearance of the invasive species could indicate that a deliberate introduction occurred. Some individuals of O. limosus were $100 \mathrm{~mm}$ long or more (Figure 8). Based on their size, various individuals were considered to be of reproductive age.

It has already been demonstrated that infected individuals of the spiny-cheek crayfish pose a dramatic 


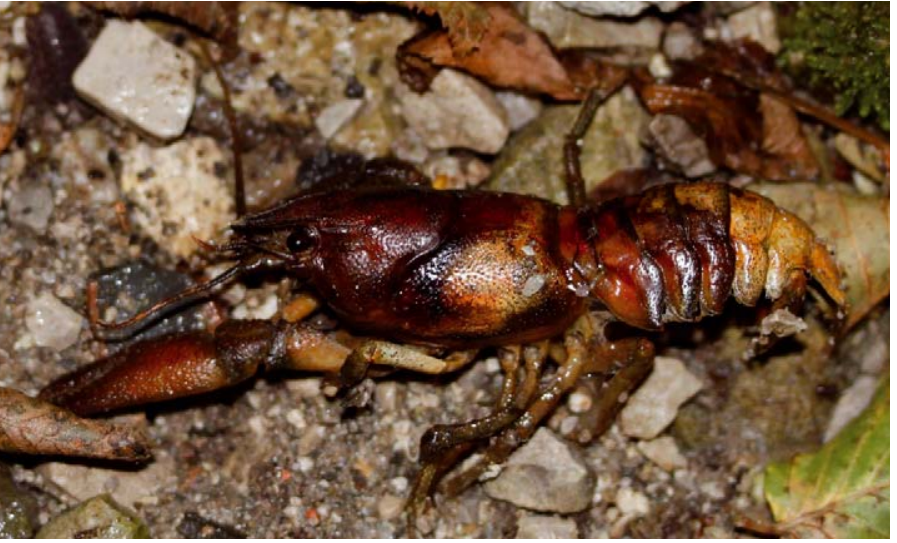

Figure 4 - Dead white-clawed crayfish, San Michele creek, 26 July 2013. (C) M. Bonelli 2013

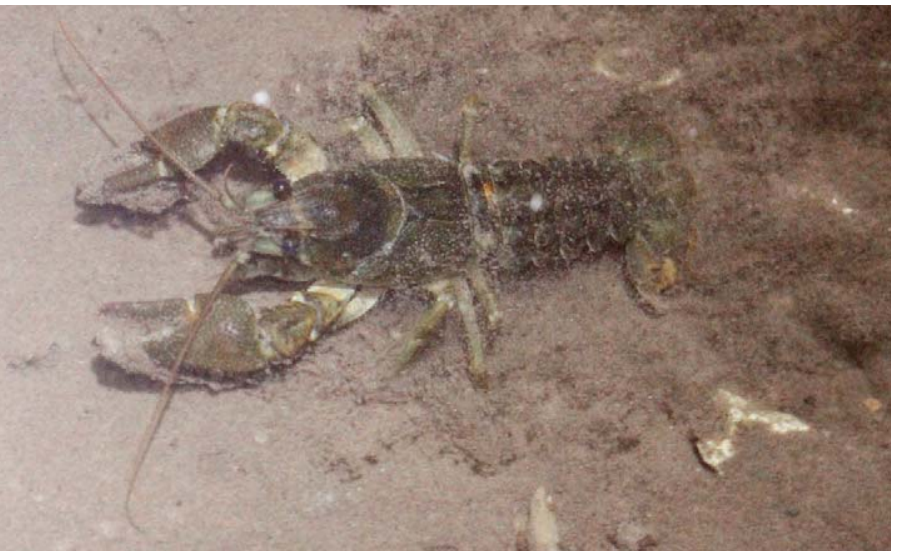

Figure 5-Moribund white-clawed crayfish, San Michele creek, 26 July 2013. (C) M. Bonelli 2013

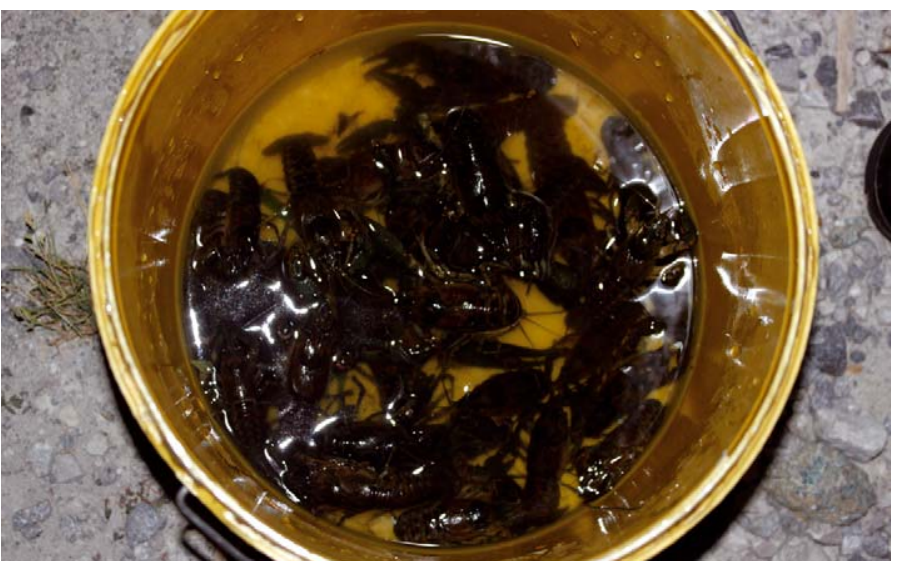

Figure 6 - Some individuals of the spiny-cheek crayfish, collected in the San Michele creek, 26 July 2013. (C) M. Bonelli 2013

threat for the native European species (Holdich et al. 2009; Oidtmann 2012). Indeed, the transmission of the crayfish plague pathogen can occur via the movement of infected specimens, or through contaminated water or equipment (Oidtmann 2012). The pathogen can also be transported through the digestive tracts of cold-blooded animals (Svoboda et al. 2016). In addition, crayfish predators (mammals, birds and fishes) can carry infected hosts to other water bodies (Evans \& Edgerton 2002; Svoboda et al. 2016).
O. limosus shows a high dispersal rate (Puky \& Schád 2006; Pârvulescu et al. 2012), influenced by water temperatures (Gherardi 2002; Buřič et al. 2009) and population densities (Taugbøl et al. 1993; Vrålstad et al. 2006). It is known that artificial and natural barriers can prevent crayfish movements and the upstream spread of the crayfish plague (Light 2003; Dana et al. 2011; Frings et al. 2013; Rahel et al. 2013; Kozubíková-Balcarová et al. 2014; Manenti et al. 2014; Benejam et al. 2015; Collas et al. 2016). In San Michele creek, the 60-metre high waterfall and the irregular presence of water can hinder the upstream movement of the alien species. Indeed, possibly due to the presence of these natural barriers, the invasive crayfishes were never reported in the San Michele creek before the 2013, despite their occurrence in the river Adda (Manenti 2006, and pers. obs.).

To understand the role played by users of the PA in the freshwater crayfish extinction that occurred in our study locality, information was collected by talking with local people. People in the area knew of the presence of the white-clawed crayfish, and the occurrence of the invasive crayfish species $P$. clarkii. In fact, some of them spoke of a red crayfish (possibly referring to the red-swamp crayfish, $P$. clarkii) as the only terrible and invasive crayfish species that was hitting the native one. However, they erroneously reported the presence of the autochthonous species in the river Adda, and the possibility of bringing specimens up to the San Michele creek in a homemade population restoration. Therefore, it is possible that the good faith of locals caused the spread of the spiny-cheek crayfish in the upper part of the creek, causing the extinction of the native crayfish population. It is probable that O. limosus specimens were found in the Adda, misidentified as the native species, and then introduced to the San Michele creek by locals.

Our report highlights the strong impact that humans may have as vectors of alien species, even in isolated mountain PAs. Moreover, this study emphasizes how prompt action following the introduction of alien crayfish species may be successful. Our results show that the alien $O$. limousus was completely eradicated within two months of its introduction. This successful eradication paves the way for further studies to evaluate the feasibility of a reintroduction of the white-clawed crayfish $A$. pallipes complex in this area, with insights of potential interest for other European mountain PAs. In fact, earlier studies have reported the possibility of restoring native freshwater crayfish populations after a minimum three-year absence of the host (Smith \& Söderhäll 1986; Taugbøl et al. 1993; Souty-Grosset et al. 2006).

The extinction of an endangered aquatic species in a SCI in a regional park which we report here underlines the need for the careful management of freshwater habitats in mountain PAs. As the populations of different native crayfish species are becoming more and more isolated and confined to spring zones and head- 
waters, mountain areas are likely to become the last refuges for several threatened species. Moreover, our study shows that in mountain parks users may release dangerous allochthonous species in pools and streams, even when they are isolated from the surrounding hydrographic networks. In this paper, we underline the need to ensure adequate surveillance of aquatic ecosystems in mountain PAs. The risks of public access to water bodies where endangered aquatic species occur should be carefully evaluated.

\section{Acknowledgments}

We thank the Monte Barro Regional Park for collaboration, and the WWF Lecco volunteers for their help. We are grateful to Prof. Morena Casartelli for the careful revision of the manuscript, and to Mary Rigby for the professional English revisions.

\section{References}

Alderman, D.J. 1996. Geographical spread of bacterial and fungal diseases of crustaceans. Scientific and Technical Review of the Office International des Epizooties 15 (2): 603-632.

ALPARC 2016. Rapport annuel 2015. Réseau alpin des espaces protégés, Chambéry. [In French]

Benejam, L., S. Saura-Mas, J. Montserrat, F. Torres \& M. Macies 2015. Could electric fish barriers help to manage native populations of European crayfish threatened by crayfish plague (Aphanomyces astaci)? Management of Biological Invasions 6(3): 307-310.

Brusconi, S., S. Bertocchi, B. Renai, M. Scalici, C. Souty-Grosset \& F. Gherardi 2008. Conserving indigenous crayfish: Stock assessment and habitat requirements in the threatened Austropotamobius italicus. Aquatic Conservation-Marine and Freshwater Ecosystems 18: 1227-1239.

Buřič, M., A. Kouba \& P. Kozák 2009. Seasonal migrations of Orconectes limosus (Rafinesque, 1817) to a small tributary of large river. In: Buřič, M. (ed.), Biology of spiny-cheek crayfish (Orconectes limosus, Rafinesque, 1817) under conditions of the Czech Republic and the study of factors influencing its invasive spreading: 55-61. OAI, Czech Republic.

Capinha, C., E.R. Larson, E. Tricarico, J.D. Olden \& F. Gherardi 2013. Effects of Climate Change, Invasive Species, and Disease on the Distribution of Native European Crayfishes. Conservation Biology 27(4): 731-740.

Chessman, B.C. 2013. Do PAs benefit freshwater species? A broad-scale assessment for fish in Australia's Murray-Darling Basin. Journal of Applied Ecology 50: 969-976.

Chucholl, C. 2013. Invaders for sale: trade and determinants of introduction of ornamental freshwater crayfish. Biological invasions 15: 125-141.

Collas, M., T. Becking, M. Deply, M. Pflieger, P. Bohn, J. Reynolds \& F. Grandjean 2016. Monitoring

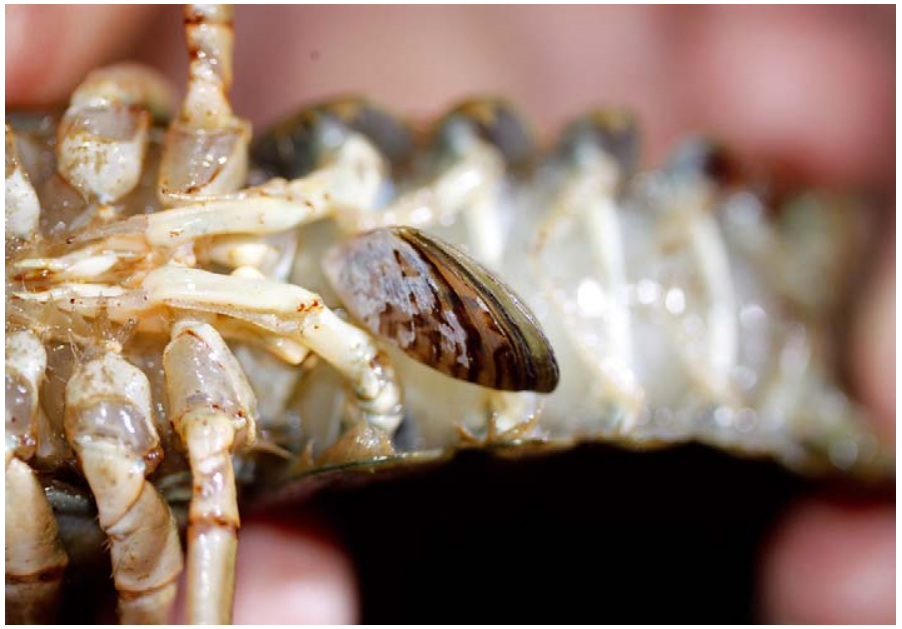

Figure 7 - Spiny-cheek crayfish male with D. polymorpha, San Michele creek, 26 July 2013. (C) M. Bonelli 2013

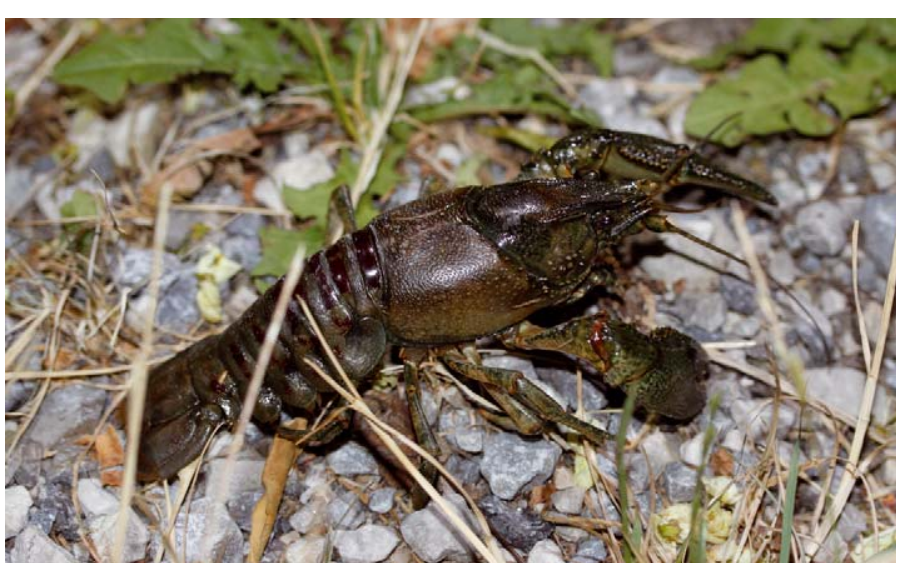

Figure 8-An individual (100 mm long) of the spiny-cheek crayfish, San Michele creek, 30 July 2013. (C) M. Bonelli 2013

of white-clawed crayfish (Austropotamobius pallipes) population during a crayfish plague outbreak followed by rescue. Knowledge and Management of Aquatic Ecosystems 417: 1.

Cornalia, E. 1860. Sulla malattia dei gamberi. Atti della Società Italiana delle Scienze Naturali 2: 334-336. In Italian]

DAISIE 2009. Handbook of alien species in Europe. Dordrecht.

Dana, E.D., J. García-de-Lomas, R. González \& F. Ortega 2011. Effectiveness of dam construction to contain the invasive crayfish Procambarus clarkii in a Mediterranean mountain stream. Ecological Engineering 37: 1607-1613.

Edgerton, B.F., P. Henttonen, J. Jussila, A. Mannonen, P. Paasonen, T. Taugbøl, L. Edsman \& C. SoutyGrosset 2004. Understanding the Causes of Disease in European Freshwater Crayfish. Conservation Biology 18(6): 1466-1474.

Evans, L.H. \& B.F. Edgerton 2002. Pathogens, Parasites and Commensals. In: Holdich, D.M. (ed.), Biology of freshwater Crayfish: 377-438.

Fea, G., P.A. Nardi, D. Ghia, M. Spairani, R. Manenti, S. Rossi, M. Moroni \& F. Bernini 2006. Dati pre- 
liminari sulla distribuzione in Lombardia dei gamberi d'acqua dolce autoctoni e alloctoni. Atti Museo Civico di Scienze Naturali di Milano 147: 201-210. [In Italian]

Ficetola, G.F., M.E. Siesa, R. Manenti, L. Bottoni, F. De Bernardi \& E. Padoa-Schioppa 2011. Early assessment of the impact of alien species: differential consequences of an invasive crayfish on adult and larval amphibians. Diversity and Distributions 17: 1141-1151.

Frings, R.M., S.C.K. Vaeßen, H. Groß, S. Roger, H. Schüttrumpf \& H. Hollert 2013. A fish-passable barrier to stop the invasion of non-indigenous crayfish. Journal of the North American Benthological Society 30: 1129-1137.

Füreder, L., F. Gherardi, D. Holdich, J. Reynolds, P. Sibley \& C. Souty-Grosset 2010. Austropotamobius pallipes. The IUCN Red List of Threatened Species 2010: e.T2430A9438817. Available at: http://www.iucnredlist.org/details/2430/0 (accessed: 24/09/2016)

Gerlach, J., M.J. Samways, A. Hochkirch, M. Seddon, P. Cardoso, V. Clausnitzer, N. Cumberlidge, B.A. Daniel, S. Hoffman Black, J. Ott \& P. Williams 2014. Priorizing non-marine invertebrate taxa for Red Listing. Journal of Insect Conservation 18: 573-586.

Gherardi, F. 2002. Behaviour. In: Holdich, D.M. (ed.), Biology of Freshwater Crayfish: 258-290. London, $\mathrm{UK}$.

Gherardi, F. 2007. Biological invasions in inland waters: an overview. In: Gherardi, F. (ed.), Biological invaders in inland waters: Profiles, distribution, and threats: 3-25. Invading Nature: Springer Series in Invasion Ecology. Dordrecht

Gozlan, R.E., E.J. Peeler, M. Longshaw, S. St-Hilaire \& S.W. Feist 2006. Effect of microbial pathogens on the diversity of aquatic populations, notably in Europe. Microbes and Infection 8(5): 1358-1364.

Holdich, D.M., J.D. Reynolds, C. Souty-Grosset \& P.J. Sibley 2009. A review of the ever increasing threat to European crayfish from non-indigenous crayfish species. Knowledge and Management of Aquatic Ecosystem 394-395: 11.

Hulme, P.E. 2009. Trade, transport and trouble: managing invasive species pathways in an era of globalization. Journal of Applied Ecology 46: 10-18.

Kozák, P., L. Füreder, A. Kouba, J. Reynolds \& C. Souty-Grosset 2011. Current conservation strategies for European crayfish. Knowledge and Management of Aquatic Ecosystems 401: 01

Kozubíková-Balcarová, E., L. Beran, Z. Ďuriš, D. Fischer, I. Horká, J. Svobodová \& A. Petrusek 2014. Status and recovery of indigenous crayfish populations after recent crayfish plague outbreaks in the Czech Republic. Ethology Ecology \& Evolution 26: 299-319.

Light, T. 2003. Success and failure in a lotic crayfish invasion: the roles of hydrologic variability and habitat alteration. Freshwater Biology 48: 1886-1897.

Lowe, S., M. Browne, S. Boudjelas \& M. De Poorter 2000. 100 of the world's worst invasive alien species. A selection from the Global Invasive Species Database.
Aliens 12: 1-12. Available at: http://www.issg.org (accessed: 24/09/2016)

Manenti, R. 2006. Rilievi sul patrimonio astacicolo della provincia di Lecco. Università degli Studi di Milano. Unpublished Thesis. [In Italian]

Manenti, R., M. Bonelli, D. Scaccini, A. Binda \& A. Zugnoni 2014. Austropotamobius pallipes reduction vs. Procambarus clarkii spreading: Management implications. Journal for Nature Conservation 22: 586-591.

Marazzi, S. 2002. L’Orografia delle Prealpi Varesine e delle Aree Limitrofe nell'ottica della 'SOIUSA'. Lombardia Nord-Ovest 1/2002: 21-44. [In Italian]

Markovic, D., S. Carrizo, J. Freyhof, N. Cid, S. Lengyel, M. Scholtz, H. Kasperdius \& W. Darwall 2014. Europe's freshwater biodiversity under climate change: distribution shifts and conservation needs. $\mathrm{Di}$ versity and Distributions 20(9): 1097-1107.

Martinati, P. 1861. Nota sulla malattia dei gamberi, che ammorbò le acque del veronese nel 1861. Memorie dell'accademia d'agricoltura, commercio ed arti, ed. tipografia Vicentini e Franchini XLI: 215-223. [In Italian]

Nardi, P.A., F. Bernini, T. Bo, A. Bonardi, G. Fea, D. Ghia, A. Negri, E. Razzetti, S. Rossi \& M. Spairani 2005. Status of Austropotamobius pallipes complex in the watercourses of the Alessandria province (N-W Italy). Bulletin Français de la Pêche et de la Pisciculture 376-377: 585-598.

Ninni, A.P. 1865. Sulla mortalità dei gamberi (Astacus fuviatilis L.) nel Veneto e più particolarmente nella provincia trevigiana. Atti Istituto Veneto Serie III 10: 1203-1209. [In Italian]

Oidtmann, B. 2012. Crayfish Plague (Aphanomyces astaci). In: OIE (eds.), Manual of Diagnostic Tests for Aquatic Animal 2015: 101-118. OIE (World Organisation for Animal Health). Available at: http:/ /www.oie. int/international-standard-setting/aquatic-manual/ access-online/ (accessed: 24/09/2016)

Pârvulescu, L., A. Schrimpf, E. Kozubíková, S. Cabanillas Resino, T. Vrålstad, A. Petrusek \& R. Schulz 2012. Invasive crayfish plague on the move: first detection of the plague agent Aphanomyces astaci in the Romanian Danube. Disease of Aquatic Organisms 98: 85-94.

Puky, M. \& P. Schád 2006. Orconectes limosus colonises new areas fast along the Danube in Hungary. Bulletin Français de la Pêche et de la Pisciculture 380-381: 919-926.

Rahel, F.J. 2013. Intentional Fragmentation as a Management Strategy in Aquatic Systems. Bioscience 63: 362-372.

Sala, O.E., F.S. Chapin, J.J.A. Kinzig, R. Leemans, D.M. Lodge, H.A. Mooney, M. Oesterrheld, N. LeRoy Poff, M.T. Sykes, B.H. Walker, M. Walker \& D.H. Wall 2000. Global Biodiversity Scenarios for the Year 2100. Science 287: 1770.

Schauer, J., M. Meikl, A. Gimeno \& R. Schwarzenbacher 2012. Larval monitoring of fire salamanders within a Sparkling Science Project. eco.mont-Journal on Protected Mountain Areas Research 4(2): 41-44. 
Smith, V. \& K. Söderhäll 1986. Crayfish pathology: an overview. Freshwater Crayfish 6: 199-211.

Söderhäll, K. \& L. Cerenius 1999. The crayfish plague fungus: history and recent advances. Freshwater Crayfish 12: 11-36.

Souty-Grosset, C., D.M. Holdich, P.Y. Noël, J.D. Reynolds \& P. Haffner 2006. Atlas of Crayfish in Europe. Collection Patrimoines naturels, 64, Muséum National d'Histoire Naturelle, Paris

Strayer, D.L. 2010. Alien species in fresh waters: ecological effects, interactions with other stressors, and prospects for the future. Freshwater Biology 55 (Suppl. 1): 152-174.

Svoboda, J., A. Mrugała, E. Kozubíková-Balcarová \& A. Petrusek 2016. Hosts and transmission of the crayfish plague pathogen Aphanomyces astaci: a review. Journal of Fish Diseases 2016: 1-14.

Taugbøl, T., J. Skurdal \& T. Håstein 1993. Crayfish plague and management strategies in Norway. Biological Conservation 63: 75-82.

Vrålstad, T., T. Håstein, T. Taugbøl \& A. Lillehaug 2006. Krepsepest - smitteforshold i norske vassdrag og forebyggende tiltak mot videre spredning av krepsepest. Veterinarinstituttes rapportserie: 1-25. Available at: www.vetinst.no (accessed: 24/09/2016) [In Norwegian]

Westman, K., R. Savolainen \& M. Julkunen 2002. Replacement of the native crayfish Astacus astacus by the introduced species Pacifastacus leniusculus in a small, enclosed Finnish lake: a 30-year study. Ecography 25(1): 53-73.

Zimmerman, J.K.M. \& R.T. Palo 2011. Reliability of catch per unit effort (CPUE) for evaluation of rein- troduction programs - A comparison of the mark-recapture method with standardized trapping. Knowledge and Management of Aquatic Ecosystems 401: 07.

\section{Authors}

\section{Marco Bonelli}

is a $\mathrm{PhD}$ student in Environmental Sciences at the Department of Biosciences, Università degli Studi di Milano (Italy), where he is working in the field of insect physiology. He is also interested in anthecology and astacology. Department of Biosciences, Università degli Studi di Milano, Italy. Email: marco.bonelli@, unimi.it

\section{Raoul Manenti}

has a PhD in animal biology; he carries out research in various fields of zoology, from developmental biology to herpetology, biospeleology and conservation. Department of Biosciences, Università degli Studi di Milano, Italy. The Mohamed bin Zayed Species Conservation Fund, project no. 162512949. Email: raoulmanenti@gmail.com

\section{Davide Scaccini - Corresponding author}

has a degree in Agricultural Sciences from the Università Cattolica del Sacro Cuore, Piacenza (Italy). He is interested in entomology, astacology, ecology, and terrestrial slugs as crop pests. Associazione WWF Lecco, Località Camporeso, Galbiate, Lecco, Italy. Email: davide.scaccini@alice.it 